\title{
Fragmentation of Araucaria araucana forests in Chile: quantification and correlation with structural variables
}

\author{
Juan Ramón Molina ${ }^{(1)}$, Ángela \\ Martín $^{(2)}$, Fernando Drake ${ }^{(3)}$, \\ Luis Miguel Martín ${ }^{(4)}$, Miguel \\ Ángel Herrera ${ }^{(1)}$
}

\begin{abstract}
Landscape fragmentation is one of the main threats to South American temperate forests due to population growth, conversion of native forests to plantations of exotic species and non-sustainable timber harvesting. The lack of forest connectivity can interfere with pollination, seed dispersal, biodiversity and landscape quality. Species with relatively limited seed dispersal are potentially more sensitive to the landscape fragmentation. Araucaria araucana (Mol.) K. Koch is a long-lived, slow-growing, relict conifer in South America's temperate forests with large seeds possessing a limited dispersal range. The objective of the study was to identify priority areas for Araucaria conservation based on fragmentation quantification and correlation with structural variables and regeneration conditions. Results from the FRAGSTATS ${ }^{\circledR}$ and CONEFOR $^{\circledR}$ software indicated that Araucaria connectivity has increased in sites located in the central Andean Range in comparison to other sites, because of reduced human and livestock pressure as well as the relative absence of commercial plantations. The proximity index ranged from $6.01 \mathrm{~m}$ to $34834.2 \mathrm{~m}$, and the probability of connectivity has significantly increased (175663 ha) in the central Andean Range. Significant relationships were found between the Simpson's index (or the probability of connectivity) and basal area, and between the mean largest patch index and crown diameter. The largest patch index $(r=$ $0.6 ; \mathrm{p}<0.05)$ and the area-weighted mean proximity index $(r=0.767 ; \mathrm{p}<$ 0.05 ) were the most important landscape metrics influencing Araucaria regeneration. Furthermore, the integration of spatial pattern analysis obtained from satellite images and aerial photographs with forest and regeneration characterization from field sampling allowed to identify the most vulnerable areas. The methodology presented here can assist in the identification of target areas for spatial conservation, including management needs under the current budget restrictions.
\end{abstract}

Keywords: Landscape Conservation, Landscape Metrics, Landscape Connectivity, Spatial Pattern Indicators

al. 2007). Forest fragmentation is known to impact landscape quality, biodiversity and wildlife survival (Aguayo et al. 2009, Piotti 2009, Tattoni et al. 2010, Rojas et al. 2011, Echeverría et al. 2012, Becerra \& Simonetti
(1) Departamento de Ingeniería Forestal, Escuela Técnica Superior de Ingeniería Agronómica y de Montes, Edificio Leonardo Da Vinci, Campus de Excelencia Internacional Agroalimentario (ceiA3), Universidad de Córdoba, ES-14071 Córdoba (Spain); (2) Departamento de Ingeniería del Medio Agronómico y Forestal, Avda. Virgen del Puerto 2, Centro Universitario de Plasencia, Universidad de Extremadura, ES-10600 (Spain); (3) Departamento de Manejo de Bosques y Medioambiente, Facultad de Ciencias Forestales, Universidad de Concepción, Casilla 160-C, Concepción (Chile); (4) Departamento de Genética, Escuela Técnica Superior de Ingeniería Agronómica y de Montes, Edificio Gregor Mendel, Campus de Excelencia Internacional Agroalimentario (ceiA3), Universidad de Córdoba, ES-14071 Córdoba (Spain)

@ Juan Ramón Molina (092momaj@uco.es)

Received: Jul 14, 2014 - Accepted: May 04, 2015

Citation: Molina JR, Martín Á, Drake F, Martín LM, Herrera MÁ (2015). Fragmentation of Araucaria araucana forests in Chile: quantification and correlation with structural variables. iForest 9: 244-252. - doi: 10.3832/ifor1399-008 [online 2015-08-28]

Communicated by: Matteo Garbarino
2013, Vergara et al. 2013). Approximately $40 \%$ of native forests (CONAF 1999) have been destroyed due to human population growth, conversion of natural landscapes to urban use (Jha \& Bawa 2006), conversion of native forests to plantations of exotic species (Pauchard \& Alaback 2006), and non-sustainable timber harvesting (Donoso 1998).

Araucaria araucana (Mol.) K. Koch (henceforth: Araucaria) is a long-lived, slow-growing, relict conifer in South America's temperate forests with high cultural, social and economic importance (Aagesen 1998a, 1998b, Ladio 2001, Herrmann 2005, 2006). Araucaria is listed as "vulnerable" (IUCN 1996) and a "national monument of Chile" (Supreme Decree 43 and Native Forest Law); designations that consolidate both landscape protections and harvesting prohibition for the species. Since it is illegal to cut Araucaria, there have been a number of efforts (mainly from private landowners who cover about $52 \%$ of its spatial distribution) to find benefits or profits that can be derived from these forests such as carbon storage and recreational activities. 


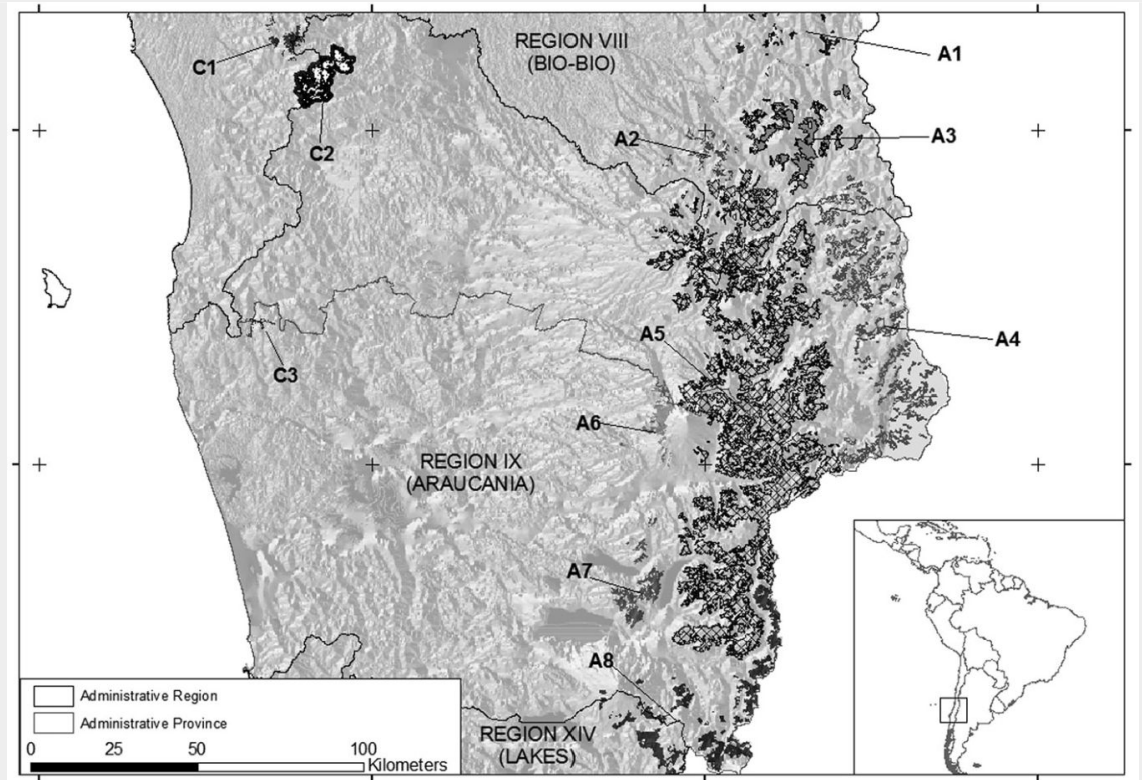

Fig. 1 - Location of the study sites and A. araucana forest range in central Chile.

Araucaria has two regeneration strategies: vegetative regeneration by sprouting and root suckering and germinative regeneration (Veblen 1982, Enright et al. 1999). Araucaria seedlings tend to establish beneath parent trees because of the limited dispersal range of its large seeds (Caro 1995, Sanguinetti \& Kitzberger 2009). If seedlings immediately colonize gaps and open areas created by dead trees, they can develop into the canopy layer (González et al. 2006). It also colonizes disturbed areas such as volcanic ash deposits and lava flows and survives in areas with suppressed conditions and wildfire (Burns 1993, Veblen et al. 1999, González et al. 2005, González \& Veblen 2006). Dynamic succession can be limited by masting, seed predation and understory vegetation effects (Sanguinetti \& Kitzberger 2009). Although the species possesses a cone production masting pattern, environmentally-triggered, intermittent, moderately-fluctuating, and regionally-synchronous seed predation is compatible even with a low production of seeds (Finckh \& Paulsch 1995, Veblen et al. 1996). Araucaria regeneration can be strongly altered by livestock and wildlife, mainly Sus scrofa L. (González et al. 2006, Sanguinetti \& Kitzberger 2010, ZamoranoElgueta et al. 2012).

High rates of deforestation and habitat fragmentation were found on the Chilean Coastal Range (Bustamante \& Castor 1998, Donoso 2006, Grez et al. 2006). Araucaria forests located in the Coastal Range were often surrounded by plantations due to the progressive conversion of native forests to plantations of exotic species (Bustamante \& Castor 1998). While plantations and urban areas are generally aggregated, native forests are often more fragmented. New business projects associated with the timber industry have expanded rapidly, requiring the development of new plantations of exotic species, mainly in areas with high site index and easy accessibility (Altamirano et al. 2007). In this sense, Araucaria forests can be classified as vulnerable because of their lack of commercial value on private lands, as well as their slow growth rate and poor regeneration in relation to vegetation competition and human disturbances (Drake 2004, Drake et al. 2005).

Araucaria fragmentation and the subsequent isolation of habitat patches can interfere with pollination, seed dispersal, natural regeneration and gene flow, among other ecological processes (Drake et al. 2009, Martín et al. 2014). A large number of indexes have been developed to assess the ecological impacts of landscape pattern change (Gustafson 1998, Boots 2006). Some studies have shown that the practical outcomes resulting from the application of some network indexes to ecological problems are very similar to those provided by considerably more complex, data-intensive, and spatially-explicit population models (Saura et al. 2011).

In this paper, the landscape is represented as a set of nodes (Araucaria patches) and links or connections. Landscape connectivity is analyzed within the concept of habitat availability at the landscape scale through the integral index of connectivity (IIC) and the probability of connectivity (PC Saura \& Torné 2009). Araucaria availability is based on the comparison of the area existing within Araucaria patches (intrapatch connectivity) and the area made available through connections with other Araucaria patches in the landscape (interpatch connectivity). Recent studies have presented analysis of the equivalent connectivity (EC) for these two indices, EC(IIC) and $E C(P C)$, to more adequately quantify landscape connectivity (Saura et al. 2011).

This research hypothesized that structural forest variables (Araucaria density, proportion of female trees, diameter at breast height, basal area, crown radius, canopy cover and understory cover) are correlated to the fragmentation of Araucaria patches based on landscape metrics (Simpson's index, patch density, largest patch index, proximity index and the probability of connectivity). The overall purpose of this study was to identify structural variables and regeneration conditions (in terms of Araucaria seedlings number) and their correlation with Araucaria fragmentation using remote sensing, Geographic Information Systems (GIS), FRAGSTATS ${ }^{\circledR}$ and CONE$\mathrm{FOR}^{\circledast}$ software and field data collection. The ecological, cultural and socio-economic importance of the species requires objective tools for resource allocation under budget constraints, and this study will provide information that will help in identifying priority areas for conservation. The temporal evaluation of forest change and regeneration conditions based on permanent sampling units linked to fragmentation analysis constitutes an objective framework for assessing the degree of threat to natural ecosystems.

\section{Methods}

\section{Study area}

Chile contains more than half of the worldwide range of Araucaria, covering approximately 260000 ha (CONAF 1999) in two separate areas: the Andean Range and the Chilean Coastal Range (Fig. 1). About 97\% of the Araucaria forests are restricted to the upper elevations of the Andean mountain range from Region VIII to Region XIV.

The species is located in a wide altitudinal and ecological range. In the Andean Range most of the soils are derived from ash deposited by volcanic activity (Montaldo 1974); however, the Chilean Coastal Range possesses better developed soils (granite and metamorphic textures - Peralta 1980). The climate of both mountain ranges has a Mediterranean influence reflected by a winter-maximum in precipitation and relatively dry summers (Almeyda \& Saez 1958). Annual precipitation varies between 1500 and $3000 \mathrm{~mm}$, although at higher altitudes the precipitation can reach more than $4000 \mathrm{~mm}$, the majority falling as snow. Mean annual temperature is highly variable with minimum temperatures in July and maximum temperatures in February.

\section{Spatial configuration of Araucaria forests}

We used $\operatorname{ArcGIS}^{\circledast}$ 9.3 (ESRI 2008) and ERDAS $^{\oplus}$ 9.3.2 (ERDAS 2009) to analyze the conservation and fragmentation condition of Araucaria ecosystems in Chile. Firstly, we identified Araucaria distribution using the National Mapping of Native Vegetation Resources (CONAF 1999). In order to get a finer spatial resolution for its current distribution $(30 \mathrm{~m})$, a set of Landsat scenes (Thematic Mapper and Enhanced Thematic 
Mapper) were mosaicked to be used as background for mapping (a list of cartographic materials used is in Tab. 1). Because of the size of the mosaic, a raster catalog of mosaicked map for each Araucaria site was used to organize all sites into a single countrywide database using ArcGIS. Aerial photographs were acquired because they presented advantages over remote sensing images in reference to Araucaria crown identification. We developed a single Araucaria map based on these cartographic materials (spanning from 2006 to 2011). The Delphi method was used to delimit homogeneous Araucaria sites according to geographic (longitude, latitude, accessibility and human pressures), climatologic (temperature and precipitation) and ecological (canopy and understory composition) attributes along the species distribution. Delphi is an expert survey consisting of
Tab. 1 - Cartographic material used to Araucaria forests delimitation.

\begin{tabular}{lcc}
\hline $\begin{array}{l}\text { Cartographic } \\
\text { material }\end{array}$ & $\begin{array}{c}\text { Scale or spatial } \\
\text { resolution }(\mathrm{m})\end{array}$ & Year \\
\hline National Mapping of Native Vegetation & $1: 50000$ & 1999 \\
Aerial photographs (National Forest & $1: 100000$ & $2006-2007$ \\
Corporation) & & \\
Aerial photographs (private landowners) & $1: 50000,1: 20000$ & $2009-2010$ \\
Aerial photographs (Forestry companies) & $1: 20000,1: 10000$ & $2010-2011$ \\
Landsat scenes (Thematic Mapper) & 30 & $1 / 1 / 2011,2 / 2 / 2011$ \\
Landsat scenes (Enhanced Thematic & 30 & $6 / 1 / 2010,8 / 12 / 2010$ \\
Mapper) & dependent on the site & 2011 \\
Google Earth &
\end{tabular}

two or more "rounds", in which previous

Satellite images were corrected geomerounds are given as feedback in later trically, atmospherically and topographicalrounds (Loo 2002). Experts participated in ly using ERDAS. Preparing the images rea later round and agreed on the identifica- quired the transformation to the WGS84 tion of eleven Araucaria sites (Tab. 2 and Zone 19S system, creating an overlap of Tab. 3).

Tab. 2 - Andean Range sites. (Tm): mean temperature range: (P): annual precipitation.

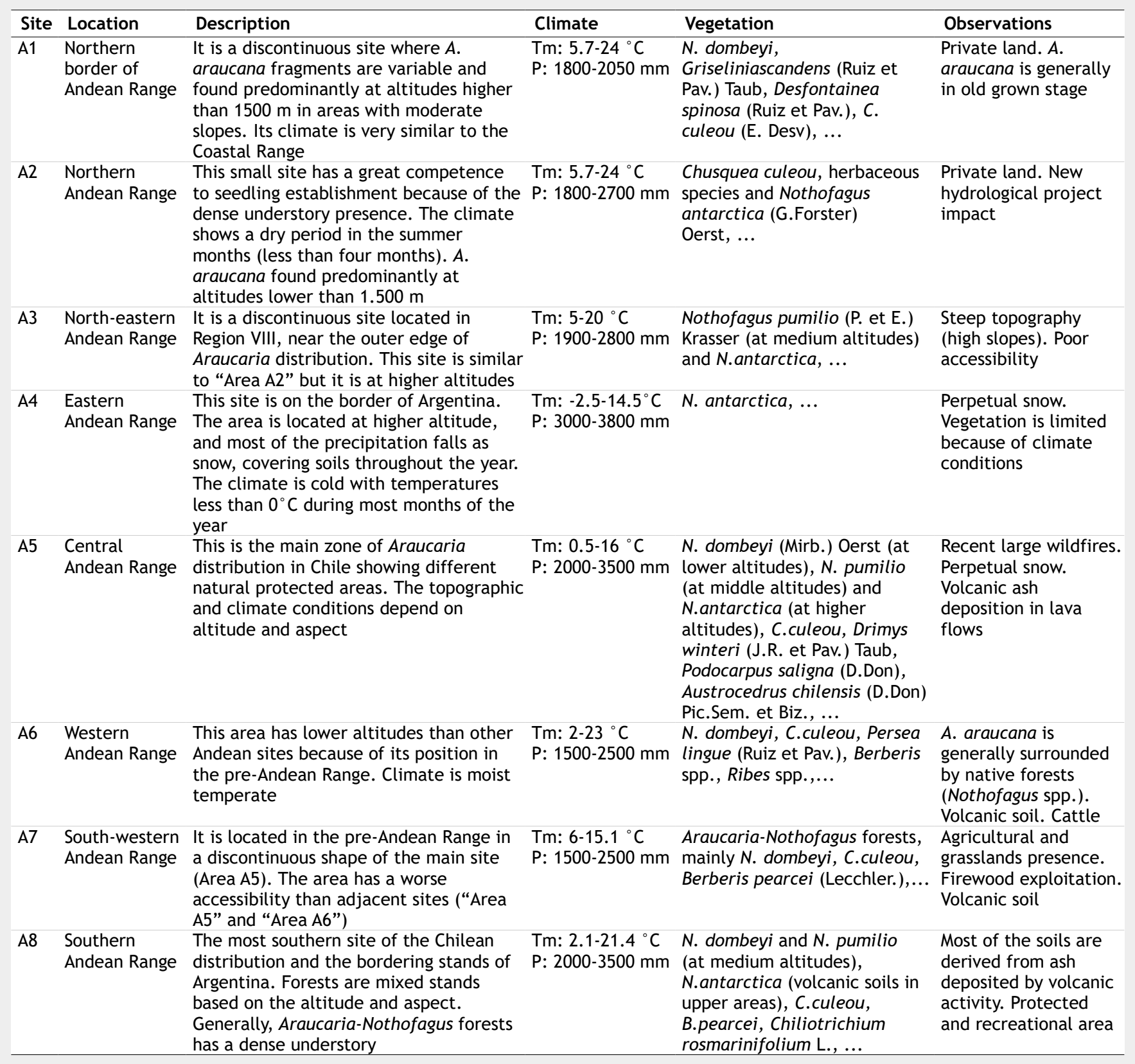


Tab. 3 - Chilean Coastal Range sites. (Tm): mean temperature range: $(\mathrm{P})$ : annual precipitation.

\begin{tabular}{|c|c|c|c|c|c|}
\hline Site & Location & Description & Climate & Vegetation & Observations \\
\hline $\mathrm{C} 1$ & $\begin{array}{l}\text { Northern Chilean } \\
\text { Coastal Range }\end{array}$ & $\begin{array}{l}\text { Topography is characterized as wavy. } \\
\text { Two dwarf populations of } A \text {. araucana } \\
\text { were found at the top of this area }\end{array}$ & $\begin{array}{l}\text { Tm: } 6.9-20{ }^{\circ} \mathrm{C} \\
\text { P: } 1.500-2.000 \mathrm{~mm}\end{array}$ & $\begin{array}{l}\text { N. dombeyi, Griselinia } \\
\text { scandens, Desfontainea } \\
\text { spinosa, C. culeou, ... }\end{array}$ & $\begin{array}{l}\text { Private land. } \\
\text { Pressure of exotic } \\
\text { species (plantations) }\end{array}$ \\
\hline $\mathrm{C} 2$ & $\begin{array}{l}\text { Nahuelbuta } \\
\text { National Park }\end{array}$ & $\begin{array}{l}\text { This area shows the highest altitudes } \\
\text { of the Coastal Range. In this area, } \\
\text { precipitation could reach } 3.000 \mathrm{~mm} \\
\text { with a dry month }\end{array}$ & $\begin{array}{l}\text { Tm: } 5.9-19.2{ }^{\circ} \mathrm{C} \\
\mathrm{P}: 2.000-3.000 \mathrm{~mm}\end{array}$ & $\begin{array}{l}\text { Nothofagus spp. (dependent } \\
\text { on the altitude gradient), C. } \\
\text { culeou, Drimys winteri, } \\
\text { Azara lanceolata (Hook F.), } \\
\text { Valeriana lapathifolia } \\
\text { (Vahl.), ... }\end{array}$ & $\begin{array}{l}\text { Protected and } \\
\text { recreational area. } \\
\text { Rocky surface. } \\
\text { Recent surface } \\
\text { wildfires }\end{array}$ \\
\hline $\mathrm{C} 3$ & $\begin{array}{l}\text { Southern Chilean } \\
\text { Coastal Range }\end{array}$ & $\begin{array}{l}\text { It is a remnant site, known as "La } \\
\text { Cabaña", located at lower elevation } \\
\text { (about } 600 \mathrm{~m} \text { ). Mean temperature } \\
\text { drops in relation to other sites of the } \\
\text { Coastal Range }\end{array}$ & $\begin{array}{l}\text { Tm: } 9-15.7{ }^{\circ} \mathrm{C} \\
\mathrm{P}: 1.500-2.500 \mathrm{~mm}\end{array}$ & $\begin{array}{l}\text { It is frequently accompanied } \\
\text { by evergreen species }\end{array}$ & $\begin{array}{l}\text { Private land. } \\
\text { Pressure of exotic } \\
\text { species (plantations) }\end{array}$ \\
\hline
\end{tabular}

using ArcGIS. The scale used allowed the identification of the following land cover types: native forest without presence of Araucaria (NF), native forest with presence of Araucaria (NFA), shrubland (S), plantations of exotic species $(P)$, agricultural and pasture lands $(A)$, water and wetlands $(W)$, urban areas (U) and bareland (B). Pixels were assigned to the land cover type of highest probability based on a supervised classification of overlapping signatures and the maximum likelihood criterion (Chuvieco 1996). Accuracy assessment involved identifying a set of sample locations (control points) that were sampled in the different field trips. A confusion matrix was obtained to compare the class identified for each control point with the land cover derived from the satellite images and aerial photographs. Overall accuracy and the Kappa index were calculated for each land cover type. Accuracy assessment was validated using a dataset of 313 random control points covering eleven Araucaria sites: eight sites in the Andean Range (Tab. 2) and three sites in the Chilean Coastal Range (Tab. 3). Then, post-classification modifications were mapped using cartographic information in GIS.

Scale refers to the "grain" or the spatial resolution of the map and "extent" refers to the map size (Turner et al. 1989, Lindenmayer \& Fischer 2006). Fine spatial resolution can identify Araucaria patches within native forest patches using aerial photo-

graphs from public agencies, forestry companies and private landowners. The boundaries of Araucaria forests were identified based on the forests' crown architecture, although there were some difficulties in pixels where Araucaria was not reaching the upper canopy layer. A minimum mapping unit of more than 0.45 ha was used (similar to other studies) because of the difficulty of small fragment assessment (Echeverría et al. 2006). Although the validation of Araucaria patches was done in the field, satellite images and aerial photographs were the only suitable tool for the geographic scale used in assessing various remote areas.

Additional information was collected by field trips in five administrative provinces: Arauco and Bio-Bio in Region VIII, Cautin and Malleco in Region IX and Valdivia in Region XIV. These provinces cover twenty municipalities (the administrative division of each province). Field trips were largely random with the exception of the edges of Araucaria sites, generally the most vulnerable areas to landscape fragmentation (Grez et al. 2006).

\section{Spatial pattern analysis}

The description of spatial patterns requires information regarding the composition (or variability) and configuration (or arrangement) of the Araucaria patches. Some landscape metrics were selected based on principles of forest fragmentation

Tab. 4 - Matrix of the Spearman's correlation coefficients of landscape metrics for the different study sites. (SI): Simpson's index calculated as (1) diversity of patch sizes and (2) as diversity of forest types; (PS): patch size; (PD): patch density, (LPI): largest patch index; (GYRATE): radius of gyration; (PROX): proximity index; $E C(I C C), E C(P C)$ : see definition in the text; $(*): P<0.05 ;\left(^{* *}\right): P<0.01$.

\begin{tabular}{llllllllll}
\hline Metrics & \multicolumn{1}{c}{$\mathrm{SI}^{1}$} & $\mathrm{SI}^{2}$ & $\mathrm{PS}$ & $\mathrm{PD}$ & LPI & GYRATE & PROX & EC(ICC) & EC(PC) \\
\hline $\mathrm{SI}^{1}$ & 1 & - & - & - & - & - & - & - & - \\
$\mathrm{SI}^{2}$ & 0.082 & 1 & - & - & - & - & - & - & - \\
PS & 0.6 & 0.036 & 1 & - & - & - & - & - & - \\
PD & $0.764^{* *}$ & 0.055 & 0.50 & 1 & - & - & - & - & - \\
LPI & 0.564 & 0.155 & 0.44 & 0.52 & 1 & - & - & - & - \\
GYRATE & $0.764^{* *}$ & 0.291 & $0.72^{*}$ & 0.54 & $0.773^{* *}$ & 1 & - & - & - \\
PROX & $0.68^{*}$ & 0.091 & $0.62^{*}$ & 0.42 & $0.64^{*}$ & $0.92^{* *}$ & 1 & - & - \\
EC(ICC) & - & 0.264 & - & -0.409 & 0.091 & - & 0.382 & 1 & - \\
EC(PC) & - & 0.136 & - & -0.409 & -0.009 & - & 0.318 & $0.982^{* *}$ & 1 \\
\hline
\end{tabular}

and the general guidelines set by various authors (Gustafson 1998, Boots 2006). We identified six landscape metrics: the Simpson's diversity index (SI), patch size (PS), patch density (PD), largest patch index (LPI), radius of gyration (GYRATE) and proximity index (PROX) by FRAGSTATs software (McGarigal \& Marks 1995). Simpson's index was calculated as one minus the sum of the proportional areas of each patch type squared. We calculated the Simpson's index both as a diversity of patch sizes and a diversity of land use types: NF, NFA, S, P, $A, W, U$ and $B$ using remote sensing images. Patch density (number of patches per 100 ha) cannot be independently interpreted as a measure of patch size. Areaweighted mean patch size was used to reduce problems related to skewed distributions of patch sizes inside each site. Largest patch index quantifies the percentage of total landscape area comprised by the largest Araucaria patch. Area-weighted mean radius of gyration (average extensiveness in meters of connected cells) is a measure of both fragment extent and habitat connectivity (Echeverría et al. 2006). Area-weighted mean proximity index (ratio between the area and the distance of patches) measures the degree of fragmentation of the Araucaria patches under three scenarios or search buffers: 250, 500 and $1000 \mathrm{~m}$, based on the size of the different sites. When the search buffer extended beyond the landscape boundary, only patches within the landscape were considered in the computations. Proximity index increases as the neighborhood (defined by the search radius) is increasingly occupied by patches of the same class, and it increases as those patches become closer and more contiguous. We constructed a correlation matrix for these landscape metrics (Tab. 4) and discarded some that were closely correlated with others $(r>0.7)$. The Simpson's index based on patch size, patch size and radius of gyration were discarded because of their correlations with patch density and proximity index.

Then, we used the CONEFOR SENSINODE software (Saura \& Torné 2009), which can characterize the degree of habitat connectivity for each Araucaria sites (mosaic of 
Araucaria patches), providing an idea of the current status of the Araucaria landscape. EC(IIC) and EC(PC) are defined as the size of a single habitat patch (maximally connected) that would provide the same value of the IIC and PC metric as the actual habitat pattern in each site. EC(IIC) and $\mathrm{EC}(\mathrm{PC})$ was computed as the square root of the numerator of the IIC and PC indices (Appendix 1). We only used EC(PC) and discarded EC(ICC) that was closely correlated (Tab. 4). EC(PC) index presents the advantages of having area units, a more reasonable and usable range of variation, and, more importantly, an easier and straightforward interpretation especially when directly compared with the temporal changes in habitat area (Saura et al. 2011).

Kruskal-Wallis non-parametric test was used to compare eleven Araucaria sites that are independent and that have different sample sizes. The parametric equivalent of the Kruskal-Wallis test is the oneway analysis of variance (ANOVA). Dunn's non-parametric post-hoc test helped identify the significant relationships among Araucaria sites and the number of Araucaria patches $\left(X^{2}=18.99, p=0.04\right)$, Simpson index based on land uses types $\left(X^{2}=\right.$ 18.88, $P=0.045)$, patch density $\left(X^{2}=19.63\right.$, $\mathrm{p}=0.03)$, largest patch index $\left(\chi^{2}=20.09, p\right.$ $=0.028)$, proximity index $\left(\chi^{2}=31.95, \mathrm{p}=\right.$ $0.001)$ and $\operatorname{ECC}(P C)\left(X^{2}=40.54, p=0.01\right)$.

Structural variables and regeneration in Araucaria forests

The forest inventory was carried out in circular plots of $1000 \mathrm{~m}^{2}$ using a stratified random sampling method. Different sampling plots were established according to Araucaria density identified by images and photographs within each location. The number of plots for each site was established proportional to the Araucaria area with the exception of the $C_{3}$ site, which was not considered. The sample amounted to 104 plots ( 4 in $A_{1}, 5$ in $A_{2}, 8$ in $A_{3}, 12$ in $A 4,45$ in $A 5,5$ in $A 6,5$ in $A 7,11$ in $A 8,5$ in $\mathrm{C}_{1}, 4$ in $\mathrm{C}_{2}$ ) located across the different Araucaria patches, incorporating variables such as stand density (trees ha-1), Araucaria density (trees ha ${ }^{-1}$ ), proportion of female trees (\%), mean diameter at breast height $(\mathrm{cm})$, basal area $\left(\mathrm{m}^{2} \mathrm{ha}^{-1}\right)$, mean crown radius $(m)$, canopy cover $(\%)$ and understory

Tab. 5 - Confusion matrix based on satellite images and aerial photographs. (NF): native forest; $(S)$ : shrubland; $(P)$ : plantation of exotic species; $(A)$ : agricultural and pasture lands; (W): water and wetlands; (U): urban area; (B): bareland.

\begin{tabular}{|c|c|c|c|c|c|c|c|c|c|}
\hline \multirow{2}{*}{$\begin{array}{l}\text { Classified } \\
\text { information }\end{array}$} & \multicolumn{7}{|c|}{ Reference data } & \multirow{2}{*}{$\begin{array}{c}\text { User's } \\
\text { accuracy } \\
\text { (\%) }\end{array}$} & \multirow{2}{*}{$\begin{array}{l}\text { Kappa } \\
\text { index }\end{array}$} \\
\hline & NF & $S$ & $\mathbf{P}$ & A & w & U & B & & \\
\hline $\mathrm{NF}$ & 50 & 6 & 0 & 1 & 7 & 0 & 0 & 78.13 & 0.7518 \\
\hline $\mathrm{S}$ & 0 & 44 & 2 & 9 & 0 & 1 & 0 & 78.57 & 0.5956 \\
\hline $\mathrm{P}$ & 1 & 0 & 37 & 1 & 0 & 0 & 0 & 94.87 & 0.9358 \\
\hline A & 2 & 0 & 1 & 50 & 0 & 1 & 0 & 92.59 & 0.9133 \\
\hline W & 0 & 0 & 0 & 5 & 33 & 0 & 0 & 86.84 & 0.8421 \\
\hline $\mathrm{U}$ & 0 & 0 & 0 & 0 & 0 & 34 & 0 & 100 & 1 \\
\hline B & 0 & 0 & 0 & 0 & 2 & 0 & 26 & 92.86 & 0.9205 \\
\hline $\begin{array}{l}\text { Producer's } \\
\text { accuracy (\%) }\end{array}$ & 94.34 & 88 & 92.5 & 75.76 & 78.57 & 94.44 & 100 & - & - \\
\hline \multicolumn{8}{|c|}{ Overall classification accuracy } & 86.21 & - \\
\hline \multicolumn{8}{|c|}{ Total Kappa Index } & - & 0.8407 \\
\hline
\end{tabular}

cover (\%). We assessed the relationship between Simpson index according to land use types, patch density, largest patch index, proximity index, $\mathrm{EC}(\mathrm{PC})$ and these structural variables. A Spearman's correlation test (non-parametric relationship) was used to identify landscape metrics that had significant relationships with forest structural variables.

Sampling data were collected for both forest structural variables and regeneration parameters in order to assess landscape condition. Regeneration data were collected in 974 subplots (within $1000 \mathrm{~m}^{2}$ plots) containing Araucaria and seedlings of other species. At least six subplots (random $100 \mathrm{~m}^{2}$ plots) were located within each sample unit. This plot size had some limitations because of the presence of "seed trees" near the plot borders. Consequently, some Araucaria seedlings were either present inside or outside of the plot. Regeneration was expressed as the number of seedlings per hectare to allow the model to be applied independently of plot size. Although the regeneration behavior for shade-tolerant species was consistent with the regeneration hypothesis associated with the competition-colonization model and spatial patterns (Drake 2004), seedlings had higher probability of reaching the canopy height in gaps created by dead trees. In this sense, all seedlings were classified by three height classes $(<50 \mathrm{~cm}$, $50-130 \mathrm{~cm}$ and $>130 \mathrm{~cm}$ ) according to other regeneration studies (Drake et al. 2012). When Araucaria regeneration is less than $50 \mathrm{~cm}$, seedlings are exposed to competition with shrub species, mainly Drimys winteri var. andina and Desfontainia spinosa, and Nothofagus, which have seedlings that colonize gaps faster than Araucaria. Seedlings over $130 \mathrm{~cm}$ in height can reach a further crown developing or polewood stage (when the tree occupies the dominant layer in the canopy - Drake et al. 2012). In addition to the landscape fragmentation analysis, a Spearman's correlation test was used to determine if there were significant relationships $(r>0.6)$ between landscape metrics and Araucaria regeneration.

\section{Results}

\section{Spatial configuration of Araucaria \\ forests}

Classification accuracy was $86.21 \%$ based on overall agreements (Tab. 5). The lowest values of user accuracy were obtained for native forests $(78.13 \%)$ and shrublands (78.57\%). Native forest (NF) was confused with water and wetland (W), likely due to similarly dark spectral responses. We used a false color image from the satellite images to solve this misclassification problem. The false-color image showed the scene in red. While plants reflected more infrared so they were brighter red, water was black and blue. Shrubland (S) was more frequently miss-reported as agricultural and

Tab. 6 - Area of each land cover class (in ha) at the A. araucana sites using a $1000 \mathrm{~m}$ buffer. (NF): native forest without presence of A. araucana; (NFA): native forest within presence of $A$. araucana; (S): shrubland; (P): plantations of exotic species; (A): agricultural and pasture lands; $(\mathrm{W})$ : water and wetlands; $(\mathrm{U})$ : urban area; (B): bareland.

\begin{tabular}{lrrrrrrrrrrr}
\hline Land use & A1 & \multicolumn{1}{c}{ A2 } & \multicolumn{1}{c}{ A3 } & \multicolumn{1}{c}{ A4 } & \multicolumn{1}{c}{ A5 } & A6 & A7 & A8 & C1 & C2 & C3 \\
\hline NF & 13365 & 16201.49 & 22931.11 & 32785.15 & 150954.48 & 7082.09 & 14686.87 & 27876.54 & 9867.12 & 9661.36 & 693.83 \\
NFA & 3475.58 & 3352.35 & 14245.27 & 23269.22 & 161512.22 & 4947.9 & 8191.02 & 25082.33 & 2992.71 & 6336.7 & 691.18 \\
S & 5410.71 & 2407.72 & 7049.01 & 31015.86 & 54022.77 & 2731.28 & 1917.31 & 5089.1 & 344.95 & 436.62 & 133.98 \\
P & 83.33 & 596.09 & 4.8 & 0 & 826.18 & 642.37 & 443.29 & 339.9 & 1194.9 & 1402.1 & 3626.8 \\
A & 3021.79 & 154.73 & 4621.46 & 25503.39 & 26310.91 & 457.62 & 1059.22 & 4830.55 & - & 723.01 & 41.82 \\
W & 40.34 & 86.99 & 277.49 & 116.69 & 2889.68 & 192.81 & 648.52 & 379.17 & 0 & 0 & 0 \\
U/B & 2049.57 & 24.24 & 6753.01 & 21771.41 & 49528.93 & 2137.37 & 68.58 & 9583.02 & 0 & 166.05 & 422.18 \\
Total & 27446.33 & 22823.62 & 55882.2 & 134461.72 & 446045.18 & 18191.45 & 27014.82 & 73180.62 & 14399.71 & 18725.84 & 5609.79 \\
\hline
\end{tabular}


Tab. 7 - Percentage of each land cover class (\%) at the A. araucana sites using a $1000 \mathrm{~m}$ buffer. (NF): native forest without presence of $A$. araucana; (NFA): native forest within presence of $A$. araucana; $(S)$ : shrubland; $(P)$ : plantations of exotic species; $(A)$ : agricultural and pasture lands; (W): water and wetlands; (U): urban area; (B): bareland.

\begin{tabular}{lrrrrrrrrrrr}
\hline $\begin{array}{l}\text { Land } \\
\text { use }\end{array}$ & A1 & A2 & A3 & A4 & A5 & A6 & A7 & A8 & C1 & C2 & C3 \\
\hline NF & 48.70 & 70.99 & 41.03 & 24.38 & 33.84 & 38.93 & 54.37 & 38.09 & 68.52 & 51.59 & 12.37 \\
NFA & 12.66 & 14.69 & 25.49 & 17.31 & 36.21 & 27.20 & 30.32 & 34.27 & 20.78 & 33.84 & 12.32 \\
S & 19.71 & 10.55 & 12.61 & 23.07 & 12.11 & 15.01 & 7.10 & 6.95 & 2.40 & 2.33 & 2.39 \\
P & 0.30 & 2.61 & 0.01 & 0 & 0.19 & 3.53 & 1.64 & 0.46 & 8.30 & 7.49 & 64.65 \\
A & 11.01 & 0.68 & 8.27 & 18.97 & 5.90 & 2.52 & 3.92 & 6.60 & 0 & 3.86 & 0.75 \\
W & 0.15 & 0.38 & 0.50 & 0.09 & 0.65 & 1.06 & 2.40 & 0.52 & 0 & 0 & 0 \\
U/B & 7.47 & 0.11 & 12.08 & 16.19 & 11.16 & 11.75 & 0.25 & 13.10 & 0 & 0.89 & 7.53 \\
\hline
\end{tabular}

Tab. 8 - Area-weighted landscape metrics assigned to each A. araucana site. Mean values in columns followed by the same letter are not significantly different $(p>0.05)$. $(*)$ : Mean values \pm standard deviation obtained under three edge zones of depth: 250, 500 and $1000 \mathrm{~m}$. (NP): number of patches; (SI): Simpson's index calculated as the diversity of land uses types. For the other column labels, see Tab. 4.

\begin{tabular}{|c|c|c|c|c|c|c|}
\hline Site & NP & SI & $\begin{array}{c}\text { PD } \\
(\mathrm{n} / 100 \mathrm{ha})\end{array}$ & $\begin{array}{l}\text { LPI } \\
\text { (\%) }\end{array}$ & $\begin{array}{l}\text { PROX* }^{*} \\
\text { (m) }\end{array}$ & $\begin{array}{c}\mathrm{ECC}(\mathrm{PC}) \\
\text { (ha) }\end{array}$ \\
\hline $\mathrm{A} 1$ & $38^{\mathrm{a}}$ & $0.52^{\mathrm{a}}$ & $0.12^{\mathrm{a}}$ & $4.4^{\mathrm{a}}$ & $6.01 \pm 1.16^{a}$ & $1680.01^{\mathrm{a}}$ \\
\hline $\mathrm{A} 2$ & $32^{\mathrm{a}}$ & $0.21^{\mathrm{b}}$ & $0.13^{\mathrm{a}}$ & $2.81^{\mathrm{b}}$ & $72.27 \pm 10.90^{b}$ & $2919.07^{a}$ \\
\hline A3 & $34^{a}$ & $0.82^{\mathrm{c}}$ & $0.054^{\mathrm{b}}$ & $12.83^{c}$ & $109.40 \pm 27.04^{b}$ & $11376.61^{\mathrm{ab}}$ \\
\hline A4 & $246^{\mathrm{b}}$ & $0.50^{\mathrm{a}}$ & $0.16^{c}$ & $2.03^{b}$ & $142.63 \pm 15.22^{b}$ & $9908.23^{\mathrm{ab}}$ \\
\hline A5 & $339^{c}$ & $0.43^{\mathrm{b}}$ & $0.067^{b}$ & $20.91^{d}$ & $34834.20 \pm 365.49^{c}$ & $175663^{\mathrm{b}}$ \\
\hline A6 & $10^{\mathrm{d}}$ & $0.29^{\mathrm{b}}$ & $0.045^{\mathrm{d}}$ & $30.13^{\mathrm{e}}$ & $268.08 \pm 0.34^{b}$ & $5873.46^{\mathrm{ab}}$ \\
\hline A7 & $9^{d}$ & $0.36^{\mathrm{b}}$ & $0.026^{e}$ & $15.38^{c}$ & $986.01 \pm 0^{d}$ & $8747.17^{\mathrm{ab}}$ \\
\hline A8 & $57^{e}$ & $0.73^{c}$ & $0.061^{\mathrm{b}}$ & $8.51^{\mathrm{a}}$ & $230.19 \pm 20.68^{b}$ & $15477.06^{\mathrm{ab}}$ \\
\hline $\mathrm{C} 1$ & $17^{f}$ & $0.68^{\mathrm{c}}$ & $0.1^{\mathrm{a}}$ & $15.45^{c}$ & $91.63 \pm 4.86^{b}$ & $2845.96^{\mathrm{a}}$ \\
\hline $\mathrm{C} 2$ & $11^{\mathrm{d}}$ & $0.76^{\mathrm{c}}$ & $0.05^{\mathrm{d}}$ & $40.97^{e}$ & $328.19 \pm 0.02^{\mathrm{e}}$ & $7986.07^{\mathrm{ab}}$ \\
\hline $\mathrm{C} 3$ & $10^{\mathrm{d}}$ & $0.63^{c}$ & $0.18^{c}$ & $15.42^{c}$ & $10.39 \pm 0.02^{a}$ & $872.84^{\mathrm{a}}$ \\
\hline
\end{tabular}

pasture land, also likely due to their similar spectral responses. Land cover cartography based on satellite images was improved using aerial photography (focusing on Araucaria crown architecture) and field trips. Control points were important for distinguishing between native forest without/with the presence of Araucaria. We analyzed Araucaria sites (Tab. 2, Tab. 3) to calculate the area and percentage of each land cover class (Tab. 6, Tab. 7). "Area C3" showed the smallest Araucaria area due to the expansion of exotic species plantations (64.65\% of the total area). Sites located on the Andean Range had less pressure from plantation establishment due to steep topography and difficult accessibility (ranging from $0 \%$ to $3.53 \%$ of the total area). Andean fragments were configured as a landscape mosaic with a very large patch $\left(A_{5}\right)$ surrounded by smaller sites. Shrubland was frequently located within the limits of Araucaria distribution, such as $\mathrm{A} 4$ and $\mathrm{A} 1$ sites (23.07\% and $19.75 \%$, respectively). Bareland was commonly found in some Andean sites such as $\mathrm{A}_{4}, \mathrm{~A}_{5}$ and $\mathrm{A} 8$. While $\mathrm{A}_{4}$ was located in relation to perpetual snow, $A 8$ was related to volcanic activity, and $A_{5}$ contained both perpetual snow and volcanic activity. Field trips showed other perturbations such as forest fires in $A_{5}$ and $C_{2}$, but Araucaria trees survived after wildfire due to its bark thickness. A new hydrological project, located between $\mathrm{A} 2$ and $\mathrm{A} 5$, proved an important anthropogenic perturbation due to the increase in the density network and land use changes.

\section{Spatial pattern analysis}

Landscape fragmentation analysis requires to consider both the patch size and the spatial configuration of Araucaria patches. While patch size was analyzed based on the number of patches, patch density and the largest patch index (the patch size was discarded previously), the quantification of the Araucaria patch connectivity was conducted according to the mean proximity index (PROX) and EC(PC). Significant relationships were found between Araucaria sites and landscape metrics. An analysis of the number of patches differences was performed among Araucaria sites showing six significant groups (Tab. 8). For example, in the Coastal Range differences were dtected for $\mathrm{C}_{1}$ in relation to $\mathrm{C}_{2}$ and $\mathrm{C}_{3}$. Higher values for the Simpson's index were recorded by $A_{3}, A 8, C_{1}, C_{2}$ and $C_{3}$ ("group $c$ ") in relation to the remaining sites. Based on patch density, the highest value in $\mathrm{C}_{3}$ ("group c") was associated with the small size of the patches. Five significant groups of Araucaria sites could be defined based on Araucaria patch density: $\mathrm{A} 1, \mathrm{~A} 2$ and $\mathrm{C}_{1}$ ("group a"); $A_{3}, A_{5}$ and $A 8$ ("group b"); $A 4$ and C3 ("group c"); C2 ("group d"); and A7 ("group e"). Differences among the sites within this same group were observed in terms of the largest patch index. As an example, the largest patch index increased from $4.4 \%$ to $15.45 \%$ in the "group a" of patch density. In the Coastal Range, the largest patch index was significantly increased in C2 ("group e") compared to C1 and C3 ("group c").

Fragmentation was accompanied by a reduction of the area-weighted mean proximity index, ranging from $6.01 \mathrm{~m}$ in $\mathrm{A} 1$ to $34834.2 \mathrm{~m}$ in A5 (Tab. 8). Mean proximity index identified five significant groups: $A 1$, C3 ("group a"); A2, A3, A4, A6, A8 and C1 ("group b"); A5 ("group c"); A7 ("group d"); and C2 ("group e"). No substantial difference between mean proximity indexes calculated at different distances was recorded. According to this result, a distance of $500 \mathrm{~m}$ could be selected as an intermediate value between other distances. For example, in the Coastal Range the area-weighted proximity index increased in $C_{2}$ in relation to $C_{1}$ and $C_{3}$. Proximity index pointed to the connectivity of $\mathrm{A}_{5}$, followed by $\mathrm{A} 7$ (values higher than $500 \mathrm{~m}$ ). An analysis of the EC(PC) was performed among Araucaria sites showing three significant groups (Tab. 8). There was a wide difference in Araucaria connectivity ranging from 872.84 ha to 175663 ha. Higher values for the $E C(P C)$ were recorded by $A_{5}$ ("group b") in relation to the rest of sites. Based on the probability of connectivity, the lowest value in $\mathrm{C}_{3}, \mathrm{~A}_{1}, \mathrm{C}_{1}$ and $\mathrm{A}_{2}$ ("group a") was associated with the small connectivity of the Araucaria patches.

\section{Structural variables and regeneration condition of Araucaria forests}

Although there were not enough data to support significant relationships between landscape metrics and some structural variables (such as mean diameter at breast height, canopy cover, Araucaria density and proportion of female trees), significant relationships (Spearman's test) were found between the basal area and the Simpson's index (calculated as a diversity of land use types) or the probability of connectivity $(r$ $=0.92, p<0.01$ and $r=0.676, p<0.05$, respectively), as well as between the mean largest patch index and the crown diame$\operatorname{ter}(r=-0.71, p<0.05)$.

Regeneration condition was measured in Araucaria seedlings (mean number of seedlings per hectare) according to the sampling design for each patch. This regeneration condition was significantly correlated to the largest patch index $(r=0.6, p<0.05)$ and to the area-weighted mean proximity index $(r=0.767, p<0.05)$. Despite such correlation was not very high, it could explain more than $75 \%$ of the sampling units, showing an important approach to identification of potential regeneration conditions from landscape fragmentation studies. In this sense, a reduction of mean proximity index was generally related to a decline in the regeneration condition of the fragments. 


\section{Discussion}

Although some authors have recommended a multi-temporal analysis of remote sensing scenes (Echeverría et al. 2006, 2007, Altamirano et al. 2007), we used the current spatial identification of Araucaria patches acquired in an accuracy assessment according to the confusion matrix (Tab. 5). In future studies, we will focus on Araucaria changes based on the spatial distribution achieved in this investigation. The overall accuracy of satellite imagery revealed that the supervised classification and the false-color image provided a suitable identification of land uses. Aerial photographs improved the identification of Araucaria inside of native forest land. The Andean Range has a lower level of accessibility than the Coastal Range due to the topography and the lower road network density. It was difficult to design sampling units and field trips along the entire distribution of the species, thus increasing the importance of satellite images and aerial photography to support land uses classification.

Area-weighted landscape metrics (patch size, patch density, largest patch index, Simpson's index, radius of gyration and proximity index) and the probability of connectivity were used to analyze the spatial pattern of eleven Araucaria sites. These landscape metrics have been frequently related to forest fragmentation by scientific studies (Gustafson 1998, Boots 2006, Echeverría et al. 2007, Long et al. 2010, Saura et al. 2011). In our study, these metrics were objective indicators in the identification of "Area C3" and "Area A1" as fragmented landscapes. Low patch connectivity was found in the Coastal Range similar to previous fragmentation approaches (Bustamante \& Castor 1998, Echeverría et al. 2006). In this sense, the remaining patches were greatly affected by plantations of exotic species ( $64.65 \%$ of the total area). Sites with low Araucaria area and more fragmented spatial pattern (like in "Area $\mathrm{C}_{3}$ " and "Area A1") will have a higher probability of suffering large decreases in connectivity than other sites with large and compact patches (like in "Area $\mathrm{A} 5$ " and "Area A8").

The fragmentation of natural landscapes could lead to changes in vegetation composition and forest structure over the medium and long term (Grez et al. 2006, Altamirano et al. 2007, Schulz et al. 2010). In our study, the Simpson's index (calculated as a diversity of land uses types) and the $E C(P C)$ significantly increased in relation to the basal area of the patches. This positive correlation could be due to the higher levels of biodiversity and basal area of the primary forests. A reduction in Simpson's index and in the probability of connectivity could be caused by the expansion of other land uses (mainly agricultural lands and plantations of exotic species) and an increase in total edge, and as a consequence, the creation of suitable sites for shrub establishment. Araucaria path density is higher in areas altered by humans than in other areas dominated by primary or virgin forests. In this sense, basal area is indirectly related to patch size, a result that has been found in other studies (Tabarelli et al. 1999, Altamirano et al. 2007, Echeverría et al. 2007). Conversely, largest patch index was negatively correlated to crown diameter. This relationship can be causality but it also could be related to the significant correlation between crown radius and stand density $(r=-0.867, p<0.01)$. The abundance of tree species increases in large patches and edge areas (Grez et al. 2006, Echeverría et al. 2007). Stand density should decrease the mean crown radius due to the competition among canopy tree species. Then, stand density could be higher in larger patches than smaller ones because of the human disturbances and the increase in edge areas of other species.

We hypothesized that regeneration condition is correlated with the fragmentation of Araucaria patches due to human disturbances and surrounding land use changes. A reduction in patch size leads to differences in seed production (Donoso et al. 2003) and microclimatic changes (Peña et al. 2008). Shade tolerant species appear to be more vulnerable to forest fragmentation than shade intolerant species because they require a certain degree of canopy protection during the first stages of growth (Bustamante \& Castor 1998). Site conditions in the larger forest patches facilitate the establishment and growth of these shade-tolerant species. A reduction of largest patch index was often related to a decline in the Araucaria seedlings. Larger Araucaria patches facilitated the establishment of shade-tolerant species. Therefore, the largest patch size is negatively associated to the edge length, so a reduction in patch size also leads to a dense establishment of invasive species (Grez et al. 2006, Echeverría et al. 2007, Becerra \& Simonetti 2013). The increased density of fast-growing species may cause a decline in the abundance of Araucaria seedlings affecting its long-term survival similar to other species (Bustamante \& Castor 1998). Our results suggest that mean proximity index was the more accurate landscape metrics to identify Araucaria regeneration. In this sense, forest connectivity may be more important than patch size in explaining changes in woody plant composition and forest structure, similar to other approaches (Tabarelli et al. 1999, Metzger 2000). Species with relatively limited seed dispersal could be potentially more sensitive to changes in the landscape matrix.

Our results indicated that gradual fragmentation is associated with changes in the structural and regeneration condition of Araucaria forests. Its long-term conservation requires the improvement of the condition of some remnant fragments, according to its cultural, social and ecological value. Special attention should be given to the sites located in the Coastal and the pre-Andean Range. Indeed, these sites showed the smallest patches, and least proximity and connectivity of Araucaria patches, and as a consequence, they are the most vulnerable landscapes over the medium and long term. Likewise, molecular markers have highlighted some of these sites as priority areas of conservation because of their high levels of genetic diversity (Martín et al. 2014). If the fragmentation process is maintained, the regeneration may be dramatically reduced. In this sense, Araucaria sites must be monitored over time and space at the landscape level. Private lands must focus on environmental services (carbon storage) and landscape goods (leisure and recreational activities) as innovative approaches for Araucaria conservation and management. Technical recommendations of the conservation priority could be established by the integration of landscape fragmentation, forest structural variables and regeneration condition. In terms of Araucaria landscape conservation, four recommendations could be given: (1) to provide incentives for the creation of biological corridors which would increase the genetic exchange of $\mathrm{C}_{1}$ and $\mathrm{C}_{2}$ sites (indicators given by other studies based on Araucaria genetic diversity should be considered - Drake et al. 2009, Martín et al. 2014); (2) to create new private protected areas and to establish collaboration agreements with private companies concerning the effects on remnant patches of A4, A5 and A8 sites, according to Araucaria fragmentation, general forest characteristics and regeneration condition; (3) to invest in tree plantation agreements with private landowners for the enrichment, densification and rejuvenation of $\mathrm{C}_{3}, \mathrm{~A}_{1}$ and $\mathrm{A}_{2}$ stands, based on Araucaria density, seed trees presence and old-grown stage; and (4) to establish actions to conserve the Araucaria landscape based on the principles of the new Native Forest Law $\mathrm{N}^{\circ}$ 20.283 (sites $A 3, A 6$ and $A 7$ ).

\section{Conclusions}

Araucaria araucana is characterized by a wide spatial distribution in Chile. Nevertheless the Araucaria landscape is presently associated with an increase in fragmentation due to human, livestock and wildlife pressures coupled with commercial plantations, mainly in the Coastal Range. Landscape fragmentation will lead to changes in forest structure and floristic composition. The conservation approach proposed in this study is based on the landscape fragmentation, forest structural variables and regeneration condition. The identification of Araucaria fragmentation using GIS, FRAGSTATS $^{\circledast}$ and CONEFOR $^{\oplus}$ increases the flexibility of this methodology, enabling an extrapolation to other territories and species. Forest data used as input in our method are easy to obtain from forest inventories. We found that the Simpson's index (calculated as a diversity of land uses 
types), the largest patch index, the areaweighted mean proximity index and the probability of connectivity are closely correlated with forest structural variables and the regeneration condition. Future studies should test if these correlations can be used to identify priority areas as an integration of landscape metrics and forest variables.

The great cultural, social and ecological importance of the Araucaria landscape calls for new tools, such as those presented here, which help analyze the potential effects of forest policy changes and contribute to sustainable landscape management. An adequate territorial planning could improve the effectiveness of conservation and land use allocation decisions based on the maintenance of Araucaria connectivity. The limitation of multi-temporal analysis inherent to this approach should be also considered. Further analyses should contemplate field sampling over time, constraints on the relationship between landscape fragmentation and forest structure, regeneration condition, and genetic diversity.

\section{Acknowledgments}

This research was partially supported by grants No. 207-141-018-1.0 from the Research Service of University of Concepción (Chile), grants A/023099/09 and A/030789/ 10 of the Spanish Agency of International Cooperation for the Development from the Spanish Ministry for Foreign Affairs and Cooperation. MAM is grateful to the Secretaría General de Ciencia y Tecnología de la Consejería de Economía, Competitividad e Innovación from the Regional Government of Extremadura (Spain) for the financial support.

\section{References}

Aagesen DL (1998a). On the northern fringe of the South American temperate forest. The history and conservation of the monkey puzzle tree. Environmental History 3: 64-85. - doi: 10.2307/3985427

Aagesen DL (1998b). Indigenous resource rights and conservation of the monkey puzzle tree (Araucaria araucana, Araucariaceae): a case study from southern Chile. Economic Botany 52: 146-160. - doi: 10.1007/BF02861203

Aguayo M, Pauchard A, Azocar G, Parra O (2009). Land use change in the south central Chile at the end of the $20^{\text {th }}$ century. Understanding the spatio-temporal dynamics of the landscape. Revista Chilena de Historia Natural 82 (3): 361-374. - doi: 10.4067/S0716-078X2009000 300004

Almeyda AE, Saez SF (1958). Recopilación de datos climáticos de Chile y mapas sinópticos respectivos [Climate data collection of Chile and their respective synoptic maps]. Ministerio de Agricultura. Santiago, Chile, pp. 195. [in Spanish]

Altamirano A, Echeverría C, Lara A (2007). Efecto de la fragmentación forestal sobre la estructura vegetacional de las poblaciones amenazadas de Legrandia concinna (Myrtaceae) del centro- sur de Chile [Effect of forest fragmentation on vegetation structure of Legrandia concinna (Myrtaceae) threatened populations in southcentral Chile]. Revista Chilena de Historia Natural 80: 27-42. [in Spanish] - doi: 10.4067/S0716$078 \times 2007000100003$

Becerra P, Simonetti J (2013). Patterns of exotic species richness of different taxonomic groups in a fragmented landscape of central Chile. Bosque 34 (1): 45-51.

Boots B (2006). Local configuration measures for categorical spatial data: binary regular lattices. Journal of Geography System 8: 1-24. - doi: 10.1007/s10109-005-0010-9

Burns BR (1993). Fire-induced dynamics of Araucaria araucana-Nothofagus antarctica forest in the southern Andes. Journal of Biogeography 20 (6): 669-685. - doi: 10.2307/2845522

Bustamante R, Castor C (1998). The decline of an endangered temperate ecosystem: the ruil (Nothofagus alessandrii) forest in central Chile. Biodiversity and Conservation 7: 1607-1626. doi: 10.1023/A:1008856912888

Caro M (1995). Producción y dispersión de semillas de Araucaria araucana (Mol.) C. Koch. en Lonquimay [Seed production and dispersal of Araucaria araucana (Mol.) C. Koch. in Lonquimay]. PhD Thesis, Facultad de Ciencias Agrarias y Forestales, University of Chile, Santiago, Chile, pp. 66. [in Spanish]

Chuvieco E (1996). Fundamentos de teledetección espacial [Fundamentals of remote sensing]. Ediciones RIALP, Madrid, Spain, pp. 447. [in Spanish]

CONAF (1999). Catastro y evaluación de los recursos vegetacionales nativos de Chile. Informe nacional con variables ambientales [Land registry and evaluation of native vegetation resources of Chile. National Report with environmental variables]. CONAF, CONAMA, BIRF, Universidad Austral de Chile, Pontificia Universidad Católica de Chile, Universidad Católica de Temuco, Ministerio de Agricultura, Santiago, Chile, pp. 88. [in Spanish]

Donoso C (1998). Bosques templados de Chile y Argentina. Variación, estructura y dinámica. Ecología forestal [Temperate forests of Chile and Argentina. Variation, structure and dynamics. Forest Ecology]. Edición Universitaria, Universidad de Chile, Santiago, Chile, pp. 484. [in Spanish]

Donoso C (2006). Las especies arbóreas de los bosques templados de Chile y Argentina. Autoecología [Tree species in temperate forests of Chile and Argentine. Autecology]. Marisa Cúneo Ediciones. Valdivia, Chile, pp. 678. [in Spanish]

Donoso D, Grez A, Simonetti J (2003). Effects of forest fragmentation on the granivory of differently sized seeds. Biological Conservation 115: 63-70. - doi: 10.1016/S0006-3207(03)00094-6

Drake F (2004). Uso sostenible en bosques de Araucaria araucana (Mol.) K. Koch. Aplicación de modelos de gestión [Sustainable Araucaria araucana (Mol.) K. Koch management. Management model alternatives]. PhD Thesis, University of Córdoba, Córdoba, Spain, pp. 318. [in Spanish]

Drake F, Herrera MA, Acuña E (2005). Propuesta de manejo sustentable de Araucaria araucana (Mol. C. Koch) [Sustainable proposal manage- ment of Araucaria araucana (Mol. C. Koch)]. Bosque 26 (1): 23-32. [in Spanish] - doi: 10.4067| S0717-92002005000100003

Drake F, Martín MA, Herrera MA, Molina JR, Drake-Martín F, Martín LM (2009). Networking sampling of Araucaria araucana (Mol.) K. Koch in Chile and the bordering zone of Argentina: implications for the genetic resources and the sustainable management. iForest 2: 207-212. doi: 10.3832/iforo524-002

Drake F, Molina JR, Herrera MA (2012). An ecophysiographic approach for Araucaria araucana regeneration management. Ciencia e Investigación Agraría 39 (1): 159-176. - doi: 10.4067/S071816202012000100013

Echeverría C, Coomes D, Salas J, Rey-Benayas JM, Lara A, Newton A (2006). Rapid deforestation and fragmented of Chilean temperate forests. Biological Conservation 130 (4): 481-494. doi: 10.1016/j.biocon.2006.01.017

Echeverría C, Newton A, Lara A, Rey-Benayas JM, Coomes D (2007). Impacts of forest fragmentation on species composition and forest structure in the temperate landscape of southern Chile. Global Ecology and Biogeography 16: 426-439. - doi: 10.1111/j.1466-8238.2007.00311.x Echeverría C, Newton A, Nahuelhual L, Coomes D, Rey-Benayas JM (2012). How landscapes change: integration of spatial patterns and human processes in temperate 60 landscapes of southern Chile. Journal of Applied Geography 32(2): 822-831. - doi: 10.1016/j.apgeog.2011.08.0 14

Enright NJ, Ogden J, Rigg LS (1999). Dynamics of forests with Araucariaceae in the western Pacific. Journal of Vegetation Science 10: 793-804. doi: $10.2307 / 3237304$

ERDAS (2009). What is the new? ERDAS Software 2009, version 9.3.2. Erdas Inc, Atlanta, Georgia, USA, pp. 12.

ESRI (2008). Arc GIS 9. Arc Map Tutorial, New York, USA, pp. 90.

Finckh M, Paulsch A (1995). The ecological strategy of Araucaria araucana. Flora 53:365-366.

González ME, Veblen T, Sibold JS (2005). Fire history of Araucaria-Nothofagus forests in Villarrica Nacional Park, Chile. Journal of Biogeography 32: 1187-1202. - doi: 10.1111/j.1365-2699.2005.0126 2.x

González M, Veblen T (2006). Climatic influences on fire in Araucaria araucana-Nothofagus forests in the Andean cordillera of south-central Chile. Ecoscience 13 (3): 342-350. - doi: 10.2980/i11956860-13-3-342.1

González ME, Cortés F, Izquierdo F, Gallo L, Echeverria C, Bekkesy S, Montaldo P (2006). Araucaria araucana (Molina) K. Koch; Araucaria, Pehuén, Piñonero, Pino Araucaria, Pino chileno, Pino del Neuquén, Monkey puzzle tree. In: "Las especies arbóreas de los Bosques Templados de Chile y Argentina. Autoecología" [Tree species in temperate forests of Chile and Argentine. Autecology]. Marisa Cúneo Ediciones. Valdivia, Chile, pp. 36-53. [in Spanish]

Grez A, Simonetti J, Bustamante R (2006). Biodiversidad en ambientes fragmentados de Chile: patrones y procesos a diferentes escalas [Biodiversity in Chilean fragmented habitats: patterns and different scales]. Editorial Universitaria, Santiago, Chile, pp. 228. [in Spanish]

Gustafson EJ (1998). Quantifying landscape spa- 
tial pattern. What is the state of the art? Ecosystems 1: 143-156. - doi: 10.1007/s100219900011 Herrmann TM (2005). Knowledge, values, uses and management of the Araucaria araucana forest by the indigenous Mapuche Pewenche people: a basis for collaborative natural re source management in southern Chile. Natura Resources Forum 29: 120-134. - doi: 10.1111/j.14 77-8947.2005.00121.x

Herrmann TM (2006). Indigenous knowledge and management of Araucaria araucana forest in the Chilean Andes: implications for native forest conservation. Biodiversity and Conservation 15: 647-662. - doi: 10.1007/s10531-005-20926

IUCN (1996). World list of threatened trees. International Union for the Conservation of Nature, Gland, Switzerland, pp. 628. [online] URL: http://www.iucn.org/themes/ssc/redlist/re dlist.htm

Jha S, Bawa KS (2006). Population growth, human development, and deforestation in biodiversity hotspots. Conservation Biology 20 (3): 906-912. - doi: 10.1111/j.1523-1739.2006.00398.x Ladio AH (2001). The maintenance of wild edible plant gathering in a Mapuche community of $\mathrm{Pa}$ tagonia. Economy Botany 55 (2): 243-254. - doi: 10.1007/BF02864562

Lindenmayer DB, Fischer J (2006). Habitat fragmentation and landscape change: an ecological and conservation synthesis. Island Press, Washington, DC, USA, pp. 352. [online] URL: http:// books.google.com/books?id=tpMKTloJixMC

Long J, Nelson T, Wulder M (2010). Characterizing forest fragmentation: distinguishing change in composition from configuration. Journal of Applied Geography 30: 426-435. - doi: 10.1016 /j.apgeog.2009.12.002

Loo R (2002). The Delphi method: a powerful tool for strategic management. International Journal of Police Strategies and Management 25 (4): 762-769. - doi: 10.1108/1363951021045 0677

Martín MA, Mattioni C, Lusini I, Molina JR, Cherubini $M$, Drake $F$, Herrera MA, Villani F, Martin LM (2014). New insights into the genetic structure of Araucaria araucana forests based on molecular and historic evidences. Tree Genetics and Genomes 10: 839-851. - doi: 10.1007/s11295014-0725-1

McGarigal K, Marks BJ (1995). FRAGSTATS: spatial pattern analysis program for quantifying landscape structure. General Technical Report PNW-GTR 351, Pacific Northwest Research Station, USDA Forest Service, USA, pp. 122.

Metzger JP (2000). Tree functional group richness and landscape structure in a Brazilian tropical fragmented landscape. Ecological Applica- tions 10: 1147-1161. - doi: 10.1890/1051-0761(200 0)010[1147:TFGRAL]2.0.CO;2

Montaldo PR (1974). La bio-ecología de Araucaria araucana (Mol.) Koch [Bioecology of Araucaria araucana (Mol.) Koch]. Boletín del Instituto Forestal Latino-Americano de Investigación y Capacitación 46-48: 1-55. [in Spanish]

Nasi R, Koponen P, Poulsen J, Buitenzorgy M, Rusmantoro W (2007). Impact of landscape and corridor design on primates in a large-scale industrial tropical plantation landscape. Biological Conservation 17 (5): 1105-1126.

Pauchard A, Alaback P (2006). Edge types defines alien plant species invasions along Pinus contorta burned, highway and clearcut forest edges. Forest Ecology and Management 223 (13): 327-335. - doi: 10.1016/j.foreco.2005.11.020 Peña E, Hidalgo M, Langdon B, Pauchard A (2008). Patterns of spread of Pinus contorta Dougl. ex Loud. invasion in a Natural Reserve in southern South America. Forest Ecology and Management 256: 1049-1054. - doi: 10.1016/j.for eco.2008.06.020

Peralta PM (1980). Geomorfología, clima y suelos del tipo forestal Araucaria en Lonquimay [Geomorphology, climate and soils of Araucaria forest type in Lonquimay]. Boletín Técnico no 55, Facultad de Ciencias Forestales, Universidad de Chile, Santiago, Chile, pp. 117. [in Spanish]

Piotti A (2009). The genetic consequences of habitat fragmentation: the case of forests. iForest 2: 75-76. - doi: 10.3832/iforo496-002

Rojas I, Becerra P, Gálvez N, Laker J, Bonacic C, Hester A (2011). Relationship between fragmentation, degradation and native and exotic species richness in an Andean temperate forest of Chile. Gayana Botanica 68 (2): 163-175. - doi: 10.4067/S0717-66432011000200006

Sanguinetti J, Kitzberger T (2009). Araucaria araucana temporal and spatial seedling establishment patterns: masting, seed predation and understory vegetation effects. Revista Chilena de Historia Natural 82: 319-335. - doi: 10.4067/S0716-078X2009000300001

Sanguinetti J, Kitzberger T (2010). Factors controlling seed predation by rodents and nonnative Sus scrofa in Araucaria araucana forests: potential effects on seedling establishment. Biological Invasion 12: 689-706. - doi: 10.1007/ s10530-009-9474-8

Saura S, Torné J (2009). Conefor Sensinode 2.2: a software package for quantifying the importance of habitat patches for landscape connectivity. Environmental Modelling and Software 24: 135-139. - doi: 10.1016/j.envsoft.2008.05.005 Saura S, Estreguil C, Mouton C, Rodríguez-Freire $M$ (2011). Network analysis to assess landscape connectivity trends: application to European forests (1990-2000). Ecological Indicators 11: 407-416. - doi: 10.1016/j.ecolind.2010.06.011

Schulz J, Cayuela L, Echeverria C, Salas J, Rey JM (2010). Monitoring land cover change of the dryland forest landscape of Central Chile (19752008). Applied Geography 30: 436-447. - doi: 10.1016/j.apgeog.2009.12.003

Tabarelli M, Mantovani W, Pérez CA (1999). Effects of habitat fragmentation on plant guild structure in the montane Atlantic forest of southern Brazil. Biological Conservation 91: 119127. - doi: 10.1016/So006-3207(99)00085-3

Tattoni C, Ciolli M, Ferretti F, Cantiani MG (2010). Monitoring spatial and temporal pattern of Paneveggio forest (northern Italy) from 1859 to 2006. iForest 3: 72-80. - doi: 10.3832/iforo530003

Turner M, O'Neill RV, Gardner RH, Milne BT (1989). Effects of changing spatial scale on the analysis of landscape pattern. Landscape Ecology 3 (3-4): 153-162. - doi: 10.1007/BF00131534 Veblen TT (1982). Regeneration patterns in Araucaria araucana forest in Chile. Journal of Biogeography 9: 11-28. - doi: 10.2307/2844727

Veblen TT, Donoso C, Kitzberger T, Rubertus AJ (1996). Ecology of southern Chilean and Argentinean Nothofagus forests. In: “Ecology and biogeography of Nothofagus forests" (Veblen TT, Hill RS, Read J eds). Yale University Press, New Haven, USA, pp. 293-353.

Veblen TT, Kitzberger T, Villalba R, Donnegan J (1999). Fire history in northern Patagonia: the roles of humans and climatic variation. Ecological Monographs 69 (1): 47-67. - doi: 10.1890/001 2-9615(1999)069[0047:FHINPT]2.0.CO;2

Vergara P, Pérez-Hernández C, Christian G, Hahn I, Soto G (2013). Deforestation in central Chile causes a rapid decline in landscape connectivity for a forest specialist bird species. Ecological Research 28 (3): 481-492. - doi: 10.1007/s11284013-1037-x

Zaizhi Z (2000). Landscape changes in a rural area in China. Landscape Urban Planning 47: 3338. - doi: 10.1016/S0169-2046(99)00069-9

Zamorano-Elgueta C, Cayuela L, Gonzalez-Espinosa M., Lara A, Parra-Vázquez M (2012). Impacts of cattle on the South American temperate forests: challenges for the conservation of the endangered monkey puzzle tree (Araucaria araucana) in Chile. Biological Conservation 152: 110-118. - doi: 10.1016/j.biocon.2012.03.037

\section{Supplementary Material}

Appendix 1 - The probability of connectivity $(P C)$.

Link: Molina_1399@supploo1.pdf 